UDC 616.36:612.393.1-092.4

LBC 54.13:54.194

\title{
EVALUATION OF THE INFLUENCE OF PRELIMINARY ALCOHOLATION ON ACTIVITY OF MICROSOMAL RAT LIVER FACTIONS IN VITRO
}

\author{
Nazar A. Osadchenko
}

Volgograd State Medical University, Volgograd, Russian Federation

Liliya P. Knyshova

Volgograd State Medical University, Volgograd, Russian Federation

Anna M. Dotsenko

Volgograd State Medical University, Volgograd, Russian Federation

Aleksandr S. Tarasov

Volgograd State Medical University, Volgograd, Russian Federation

Anatoliy T. Yakovlev

Volgograd State Medical University, Volgograd, Russian Federation

Abstract. The present research is devoted to the study of the relationship between the structure of the original synthetic monophenolic antioxidants and their ability to influence the activity of autophagy in tumor cells.

Key words: synthetic monophenolic antioxidants, autophagy, tumor cells.

УДК 616.36:612.393.1-092.4

ББК 54.13:54.194 \section{НА АКТИВНОСТЬ МИКРОСОМАЛЬНЫХ ФРАКЦИЙ ПЕЧЕНИ КРЫС IN VITRО}

\author{
Назар Андреевич Осадченко
}

Волгоградский государственный медицинский университет, г. Волгоград, Российская Федерация

\section{Лилия Петровна Кнышова}

Волгоградский государственный медицинский университет, Волгоградский медицинский научный центр, г. Волгоград, Российская Федерация

\section{Анна Михайловна Доценко}

Волгоградский государственный медицинский университет, Волгоградский медицинский научный центр, г. Волгоград, Российская Федерация

\section{Александр С. Тарасов}

Волгоградский государственный медицинский университет, г. Волгоград, Российская Федерация

\section{Анатолий Трофимович Яковлев}

Волгоградский государственный медицинский университет, г. Волгоград, Российская Федерация 
Аннотация. Настоящее исследование посвящено изучению зависимости между структурой оригинальных синтетических монофенольных антиоксидантов и их способностью влиять на активность аутофагии в опухолевых клетках.

Ключевые слова: синтетические монофенольные антиоксиданты, аутофагия, опухолевые клетки.

Введение. Печень - самая крупная железа пищеварительного тракта. Ряд метаболических реакций, протекающих в ней, лежит в основе энергетического и пластического обменов в живом организме. Печень участвует в синтезе белков, в выработке веществ для пищеварения, в обезвреживании токсических продуктов.

В процессе детоксикации участвует локализованная в мембранах эндоплазматического ретикулума система микросомального окисления [1]. К группе микросомальных ферментов относят специфические оксидазы, различные гидролазы и ферменты конъюгации [3]. Система обезвреживания включает множество разнообразных ферментов, под действием которых практически любой ксенобиотик может быть модифицирован. В метаболизме ксенобиотиков могут принимать участие ферменты почек, легких, кожи и ЖКТ, но наиболее активны они в печени.

В последнее время в большинстве исследований для учета вклада биотрансформации в биологическую активность и токсичность ксенобиотиков используют фракции микросом печени - супернатанта после центрифугирования гомогената печени при $9000 \mathrm{~g}$ (фракции S9), которая в десятки раз повышает активность ферментов семейства цитохрома Р-450 [5]. Современные исследования метаболизма ксенобиотиков часто проводятся с использованием фракции S9 - продукта центрифугирования гомогената тканей печени [6]. В ряде случаев перед подготовкой фракции необходимо применение индукторов, одним из которых может быть этанол, влияющий на экспрессию и активность NAD-зависимых оксидоредуктаз и некоторых изоферментов системы цитохрома Р450.

Цель исследования - оценить влияние хронической алкоголизации крыс на общую функциональную активность ферментативных систем гепатоцитов.

Материалы и методы. Работа выполнена на 24 крысах-самцах линии Вистар (280-350 г), содержавшихся в НИИ фарма- кологии ВолгГМУ. Животные были распределены на 2 группы: контрольную, содержавшуюся на стандартном водно-пищевом рационе, и экспериментальную с 15 \% этанолом как единственным источником жидкости [2]. Алкоголизацию животных экспериментальной группы проводили в течение 2-х недель. Для забора биологического материала животных наркотизировали однократным внутрибрюшинным введением хлоралгидрата в дозе 400 мг/кг, после чего брюшную полость вскрывали, портальную вену изолировали и катетеризировали для подключения перфузионной системы, состоящей из перистальтического насоса, емкости с перфузионным раствором, который представлял собой $0,1 \mathrm{M}$ фосфатно-солевой буфер (PBS, pH=7,4). Об эффективности перфузии судили по изменению окраски и консистенции печени. По окончании перфузии животных умерщвляли, печень извлекали, измельчали и гомогенизировали в PBS (1:4), после чего полученные гомогенаты центрифугировали при 9000 g в течение 20 минут. Определение активности ферментативных систем проводили в 96-луночных планшетах, в лунки которых вносили по 50 мкл супернатанта и 200 мкл среды RPMI, содержащей феноловый красный в качестве кислотно-основного индикатора. В качестве негативного контроля использовали супернатант, прокипяченный при $100{ }^{\circ} \mathrm{C}$ в течение 20 минут [5]. Планшеты помещали в шейкер-инкубатор (500 об/мин, $37^{\circ} \mathrm{C}$ ) на 30 минут, затем определяли абсорбцию образцов при 415 нм, что близко к максимуму поглощения кислотной формы фенолового красного. Статистическую обработку производили в программе GraphPad Prism 5.0 по U-критерию Манна - Уитни.

Результаты и исследования. Нарушения компенсаторных механизмов организма, характеризующиеся сдвигами концентрации водородных ионов, приводят к различным нарушениям кислотно-основного равновесия. Смещение кислотно-основного равновесия в кислую сторону, происходящее при работе ферментативных систем живых клеток, широко 
используется при постановке микротитрационных тестов.

В ходе оценки активности ферментативных систем гепатоцитов на фоне хронической алкоголизации было обнаружено достоверное увеличение в 3,5 раза абсорбции кислотной формы фенолового красного в лунках планшета, содержащих фракцию S9 крыс, подвергнутых алкоголизации (рис., $\mathrm{p}<0,001$ ). Данные изменения могут быть связаны с индукцией цитоплазменных оксидаз, а также микросомальных оксигеназ и ряда изоферментов систем цитохрома Р450.

Полученные результаты указывают на то, что хроническая алкоголизация может изменять экспрессию и активность окисдоредуктаз печени, что может приводить к изменению биотрансформации лекарственных средствсубстратов данного класса ферментов.

Выводы. Обнаружено статистически значимое увеличение ферментативной активности фракции S9, полученной от крыс, подвергнутых хронической алкоголизации, связанное с индуцирующим действием этанола как на микросомальные, так и на цитоплазменные ферменты.

\section{СПИСОК ЛИТЕРАТУРЫ}

1. Биохимия : учеб. для вузов / под ред. Е. С. Северина.-М. : ГЭОТАР-МЕД, 2003.-С. 779.

2. Влияние экспериментальной хронической эндогенной алкогольной интоксикации на микрофлору кишечника / Л. П. Кнышова [и др.] // Вестник Волгоградского государственного медицинского университета. - 2016. - № 4 (60). C. $40-44$.

3. Лукьянова, Е. С. Особенности системы микросомального окисления при синдроме длительного сдавления в эксперименте / Е. С. Лукьянова, Д. Б. Кузьменко, А. В. Ефремов // Бюллетень CO РАМН. - 2011. - Т. 31, № 3. - С. 68-71.

4. Оптимизация метода выделения микросомальной фракции печени крыс / Е. И. Морковин [и др.] // Волгоградский научно-медицинский журнал. - 2017. - № 1 (53). - С. 42-44.

5. Benford, D. J. Metabolizing systems in cell culture cytotoxicity tests / D. J. Benford, H. J. Reavy, S. A. Hubbard // Xenobiotica. - 1988. - Vol. 18, № 6. P. 649-656.

6. Nikolic, D. New metabolic pathways for flavanones catalyzed by rat liver microsomes / Nikolic D., van Breemen R. B. // Drug. Metab. Dispos. - 2004. $32(4) .-$ P. 387-397.

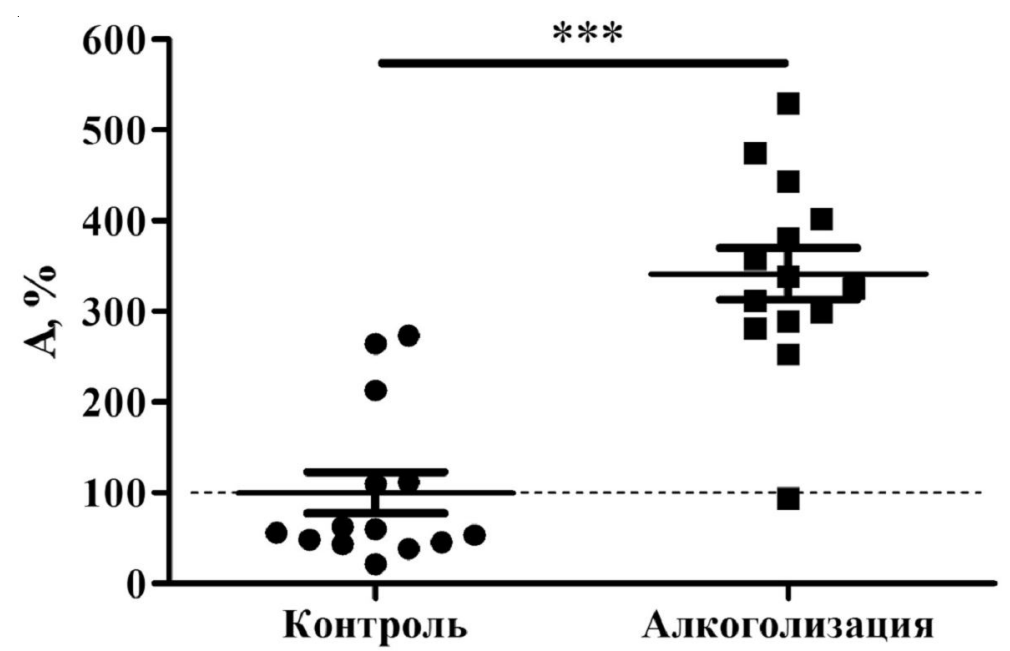

Рисунок. Относительная ферментативная активность фракции S9 печени крыс

Примечание. Данные нормализованы по среднему значению А в контроле; каждая точка соответствует среднему по 4-м биологическим повторностям; *** - p < 0,001 (U-критерий Манна - Уитни). 


\section{Information about the Authors}

Nazar A. Osadchenko, Student, Department of Fundamental Medicine and Biology, Volgograd State Medical University, Pavshikh bortsov Sq., 1, 400131 Volgograd, Russian Federation, post@volgmed.ru.

Liliya P. Knyshova, Volgograd State Medical University, Pavshikh bortsov Sq., 1, 400131 Volgograd, Russian Federation, post@volgmed.ru.

Anna M. Dotsenko, Assistant, Department of Fundamental Medicine and Biology, Volgograd State Medical University, Pavshikh bortsov Sq., 1, 400131 Volgograd, Russian Federation, post@volgmed.ru.

Aleksandr S. Tarasov, Volgograd State Medical University, Pavshikh bortsov Sq., 1, 400131 Volgograd, Russian Federation, post@volgmed.ru.

Anatoliy T. Yakovlev, Doctor of Sciences (Medicine), Professor, Department of Clinical Laboratory Diagnostics, Volgograd State Medical University, Pavshikh bortsov Sq., 1, 400131 Volgograd, Russian Federation, lemen@soramn.ru.

\section{Информация об авторах}

Назар Андреевич Осадченко, студент, кафедра фундаментальной медицины и биологии, Волгоградский государственный медицинский университет, пл. Павших борцов, 1, 400131 г. Волгоград, Российская Федерация, post@volgmed.ru.

Лилия Петровна Кнышова, Волгоградский государственный медицинский университет, Волгоградский медицинский научный центр, пл. Павших борцов, 1, 400131 г. Волгоград, Российская Федерация, post@volgmed.ru.

Анна Михайловна Доценко, ассистент, кафедра фундаментальной медицины и биологии, Волгоградский государственный медицинский университет, Волгоградский медицинский научный центр, пл. Павших борцов, 1, 400131 г. Волгоград, Российская Федерация, post@volgmed.ru.

Александр С. Тарасов, Волгоградский государственный медицинский университет, пл. Павших борцов, 1, 400131 г. Волгоград, Российская Федерация, post@volgmed.ru.

Анатолий Трофимович Яковлев, доктор медицинских наук, профессор, кафедра клинической лабораторной диагностики с курсом клинической лабораторной диагностики ФУВ, Волгоградский государственный медицинский университет, пл. Павших борцов, 1, 400131 г. Волгоград, Российская Федерация, lemen@soramn.ru. 